in vivo $32: 813-817(2018)$

doi:10.21873/invivo.11312

\title{
A Study of Short- and Long-term mRNA Levels of the Retn, Iapp, and Drd5 Genes in Obese Mice Induced with High-fat Diet
}

\author{
OZLEM TIMIRCI-KAHRAMAN ${ }^{1}$, UMIT YILMAZ ${ }^{1}$, NESIBE YILMAZ $^{1}$, AYDIN CEVIK $^{2}$, \\ CEM HOROZOGLU $^{1,3}$, FARUK CELIK ${ }^{1}$, MUHAMMED OGUZ GOKCE ${ }^{1}$, ARZU ERGEN ${ }^{1}$, \\ ABDULLAH MELEKOGLU ${ }^{4}$ and UMIT ZEYBEK ${ }^{1}$
}

\begin{abstract}
Departments of ${ }^{1}$ Molecular Medicine, ${ }^{2}$ Experimental Animal Biology and Biomedical Application Techniques, Aziz Sancar Institute of Experimental Medicine, Istanbul University, Istanbul, Turkey; ${ }^{3}$ Department of Medical Services and Techniques, Istanbul Gelisim University, Istanbul, Turkey;

${ }^{4}$ Department of Genetics and Bioengineering, Faculty of Engineering and Architecture,
\end{abstract} Kastamonu University, Kastamonu, Turkey

\begin{abstract}
Background/Aim: Adipocyte gene expression is altered in obese individuals through multiple metabolic and biochemical pathways. In this study, we aimed to examine the expression of resistin (Retn), amylin (Iapp), and dopamine receptor domain 5 (Drd5) genes previously suggested to contribute to the pathogenesis of obesity, albeit controversially. We also aimed to determine the effects on short and long-term mRNA levels of these genes in obese mice, induced with high-fat diet (HFD). Materials and Methods: Two obesity models were created in our study: group T1 (20 mice) was fed with HFD (60\% fat) for 3 months, and group T2 (20 mice) was fed with HFD (60\% fat) for 6 months. The control group T0 (20 mice) was fed with a diet of 10\% kcal fat supplement for 6 months. At the end of the experiment, their adipose tissues were dissected surgically. Tissue samples of each group were pooled for RNA isolation, cDNA synthesis was carried out and the mRNA levels were examined by quantitative real-time polymerase chain reaction. Serum resistin levels were measured using multiplex bead (luminex) technology for validation. Results. In T2 mice, the mRNA expression of Retn showed a moderate up-regulation (fold change $=8.32 ; p=0.0019$ ) in the adipose
\end{abstract}

This article is freely accessible online.

Correspondence to: Professor Dr. Umit Zeybek, Istanbul University, Aziz Sancar Institute of Experimental Medicine, Department of Molecular Medicine, Vakif Gureba Cad., Sehremini-Fatih 34093 Istanbul, Turkey. Tel: +90 2124142000 Ext. 33329, Fax: +90 2125324171,e-mail: umz67@yahoo.com

Key Words: Gene expression, C57BL/6J, Retn, Iapp, Drd5. tissues. Iapp expression was also significantly up-regulated (fold change=9.78; $p=0.012$ ). Moreover, a 6.36-fold upregulation for Drd5 was observed in the adipose tissues of T2 mice $(p<0.001)$. At the same time, serum levels of resistin were found to be high in T1 and T2 mice compared to the control group $(p<0.001$ and $p=0.024$, respectively $)$. Conclusion: Our study demonstrated that the mRNA levels of the genetic markers considered to play a role in adipogenesis were different in short- and long-term obesity models formed in C57BL/6J mice using HFD.

The definition of obesity is a pathological excessive fat accumulation in some or all parts of the body to levels sufficient to impair general health. Obesity has become a worldwide epidemic affecting millions of people from different races and ethnicities and putting them at serious health risks (1). It has since long been known that obesity has a genetic basis. Not only alterations in gene expression, but also copy number variants (CNVs), and genetic mutations have been demonstrated in cases with hereditary obesity and those with a tendency for obesity (2). Despite many genetic pathologies being detected in hereditary cases, there are no robust data on the pathogenesis of obesity.

Adipose tissue behaves like an important endocrinological organ, actively secreting many important molecules, namely adipokines or adipocytokines. Some of them may affect a wide array of metabolic and biochemical processes in the human body, including food intake and lipid and carbohydrate metabolism, making them potential culprits in the genesis of obesity (3). Altered gene expression in adipocytes also affects many biochemical and metabolic pathways in obesity, ultimately resulting in modified energy distribution between fat and other tissues. Furthermore, the relative expression of 
adipokine, a hormone released by adipocytes, is also modulated by a changed hormonal environment.

Resistin (RETN), a cysteine-rich protein, was initially found to be expressed in adipose tissue and have detectable circulating levels in humans (4). It was first examined in studies employing rodent models of obesity and insulin resistance $(5,6)$, and despite continued research, its role in obesity is still unclear. Some studies found increased levels of circulating resistin and its mRNA expression in adipose tissue in patients with obesity $(7,8)$, while other studies have failed to demonstrate this $(9,10)$.

Amylin, also referred to as islet amyloid polypeptide (IAPP), is composed of 37 amino acids. It is secreted by pancreatic beta cells simultaneously with insulin (11). Amylin receptors, when stimulated, reduce food intake and glucagon release after meals through a glucose-dependent mechanism $(12,13)$. Amylin has been indicated by some studies to play a role in the regulation of eating habits and fat mass (14-16). Despite successful progress on this topic, to our knowledge no study has yet explored IAPP with respect to its mRNA level in adipose tissue.

Dopamine acts as a transmitter in central nervous system in many physiological events and processes. There are two main dopamine receptor subclasses, namely the D1-like (DRD1 and DRD5) and D2-like (DRD2 and DRD4) (17). Recent studies have suggested that dopamine levels and receptors are also important in obesity. Studies on adipocyte cell lines and obese humans have demonstrated (dopamine receptor domain 5 (DRD5) mRNA and protein expression (18-20). Despite these data, the mRNA level of the DRD5 gene has not yet been studied in adipose tissue.

Experimental animal models, compared to clinical studies, are very important for multifactorial polygenic disorders such as obesity. In human studies, it is not reasonably possible to match nutritional factors and form a study group composed of a pure race. Our study aimed to examine the mRNA expression of the Retn, Iapp, and Drd5 genes, which were previously suggested to contribute to the pathogenesis of obesity, in the adipose tissues of long-and short-term obese mouse models induced by a high-fat diet (HFD) in an attempt to reveal potential differences in their expression.

\section{Materials and Methods}

Ethics statement. All animal care and experimental procedures were carried out in strict accordance with the guidelines for the care and use of laboratory animals of Istanbul University, and approved by the Animal Experiments Native Ethical Committee (Approval number: 25/2010). All surgeries were performed under ketamine anesthesia, and all efforts were made to minimize suffering.

Animal treatments. In this study, 8-week old-male mice of $C 57 B L / 6 J$ lineage with an initial weight of $18-20 \mathrm{~g}$ were supplied for the HFD-induced obesity model by Department of Experimental
Animal Biology and Biomedical Application Techniques, Aziz Sancar Institute of Experimental Medicine, Istanbul University, Istanbul, Turkey. The mice were housed in an air-conditioned medium with 10 to 15 air exchanges per hour at a room temperature of $21 \pm 2^{\circ} \mathrm{C}$, relative humidity of $40-60 \%$, light intensity of 40 lux, 12 hours light/ 12 hours dark, and a noise level below $85 \mathrm{~dB}$.

Animals in all groups were fed a purified feed with $10 \% \mathrm{kcal}$ fat supplement for a week of run-in period and they were then grouped into three main groups. Twenty mice in the control group (T0) were fed a purified feed with $10 \% \mathrm{kcal}$ fat supplement (Purina TestDiet巴F. No: \#58Y2, Sigma, St. Louis, MO, USA) for 6 months. Twenty mice in the first experimental group (T1) were fed a purified feed with $60 \% \mathrm{kcal}$ fat supplement (Purina TestDiet ${ }^{\circledR}$ F. No: \#58Y1, Sigma) for 3 months. Twenty mice in the second experimental group (T2) were fed the same purified feed with $60 \%$ kcal fat supplement for 6 months. All animals were provided feed and water ad libitum and their live weight gain was monitored weekly and food consumption daily.

The mean weight of T0 mice was $28 \mathrm{~g}$ at the end of 6 months, $\mathrm{T} 1 \mathrm{mice}$ had a mean weight of $39.82 \mathrm{~g}$ at the end of 3 months, and $\mathrm{T} 2$ mice had a mean weight of $43.16 \mathrm{~g}$ at the end of 6 months. The mice were sacrificed under ketamine hydrochloride anesthesia at the end of the experiment. Their adipose tissues were then collected surgically following sacrifice with cervical dislocation. At the postdissection measurements, an average of $0.73 \mathrm{~g}$ of adipose tissue was collected from the mice in group $\mathrm{T} 0,1.79 \mathrm{~g}$ from the mice in $\mathrm{T} 1$, and $1.78 \mathrm{~g}$ from the mice in $\mathrm{T} 2$.

RNA isolation and cDNA synthesis. Tissue samples obtained from each group were pooled into three groups in TRIzol reagent (Invitrogen, Carlsbad, CA, USA). RNA isolation was performed from the homogenate. A spectrophotometric quantification method was used for the RNA yield. The A260/A280 ratio was used for the determination of RNA quality, and this was confirmed by RNA agarose gel electrophoresis where the integrity of $18 \mathrm{~S}$ and $28 \mathrm{~S}$ rRNAs was observed. A High Capacity RNA-to-cDNA Master Mix synthesis kit (Applied Biosystems, Foster City CA, USA) was utilized to synthesize complementary DNA from RNA samples using $1 \mu \mathrm{g}$ template of RNA samples.

Quantitative real-time polymerase chain reaction $(Q-R T-P C R)$ and analyses. Relative RT PCR analysis was carried out with a Stratagene MX 3005P (Stratagene, La Jolla, CA, USA) using TaqMan Gene Expression Master Mix (Applied Biosystems) with mouse-specific primers. Commercial ready-to-use primers/probe mixes (Assays on Demand Products; Applied Biosystem) utilized were: Retn (Mm00445642_g1), Iapp (Mm00439403_m1) and Drd5 (Mm04210376_s1). RT-PCR reactions were carried out in $25 \mu \mathrm{l}$ volumes, with $1 \mu \mathrm{l}$ of cDNA, $12.5 \mu \mathrm{l}$ of PCR Master Mix, $300 \mathrm{mM}$ of each forward and reverse primer and $9 \mu$ of water. The Q-RT-PCR cycling conditions were $95^{\circ} \mathrm{C}$ for $10 \mathrm{~min}$ of the initial denaturing and then 40 cycles of $95^{\circ} \mathrm{C}$ for $10 \mathrm{~s}$ followed by primer annealing and extension at $60^{\circ} \mathrm{C}$ for $1 \mathrm{~min}$. The specificity of each PCR product was determined by melting-curve analysis and amplicon size determination on agarose gels. As a result of our literature review and pilot studies, we preferred $\beta$-actin gene as the housekeeping gene for RT-PCR. The fold change was calculated using the $2^{-\Delta \Delta C T}$ method originally published Livak and Schmittgen (21). The $p$-values were calculated using Student's $t$-test on the technical replicate $2-\Delta C T$ values for each gene in each treatment group compared to the control group. 
Serum resistin analysis with Luminex system. Blood samples were collected from each group at the end of the experiment. Whole blood was allowed to clot for $1 \mathrm{~h}$ at $37^{\circ} \mathrm{C}$ and spunto serum. Serum was aliquoted and stored at $20^{\circ} \mathrm{C}$ until analyzed. The serum levels of resistin were determined using BioSource and Luminex BioPlexSystems (R\&D Systems Inc., Minneapolis, MN, USA). Data were processed with Luminex ${ }^{\circledR} 200^{\mathrm{TM}}$ IS 2.3 Star Station software (Applied Cytometry, Plano, TX, USA).

\section{Results}

To validate the study data, we used the control group as the calibrator and set the gene expression level for this group to 1. The mRNA expression level of Retn showed a slight upregulation (fold change $=2.13 ; p=0.100$ ) in the $\mathrm{T} 1$ group compared to the $\mathrm{T} 0$ group. The $\mathrm{T} 2$ group also showed upregulation compared to the $\mathrm{T} 0$ group (fold change $=8.32$; $p=0.0019$ ). Compared to the T0 group, the mRNA expression of Iapp was found to be slightly up-regulated (fold change $=2.14 ; p=0.029)$ in the $\mathrm{T} 1$ group, while it was significantly up-regulated in the T2 group compared (fold change=9.78; $p=0.012)$. Drd5 mRNA expression was quite similar between the $\mathrm{T} 1$ and $\mathrm{T} 0$ groups (fold change $=0.81$; $p=0.440$ ), however, it was significantly up-regulated in the T2 group compared to the T0 group (fold change $=6.36 ; p<0.001$ ). The relative quantitation levels are shown in Figure 1.

Serum resistin levels measured after 3 and 6 months of $\operatorname{HFD}(6,561 \pm 2,226.38 \mathrm{pg} / \mathrm{ml}, p<0.001$; and 5,801 $\pm 2,348.67$ $\mathrm{pg} / \mathrm{ml}, p=0.024$, respectively) were significantly higher in both HFD groups compared to the control group $(4,353 \pm 1,230.34 \mathrm{pg} / \mathrm{ml})$.

\section{Discussion}

Excess energy results in fat accumulation in the human body over time, which leads to overweight or obesity depending on the amount of fat stored. It is yet unclear how genetic and environmental or lifestyle factors cause obesity or overweight. Many genetic studies have been conducted on hereditary obesity syndromes, as well as in overweight and acquired obesity. Although much information about obesity has been obtained from various studies, no significant success has been achieved in revealing major loci or genetic factors in nonhereditary obesity cases $(22,23)$.

Resistin is an adipocyte-specific hormone that has been suggested to be an important link between obesity, insulin resistance and diabetes $(24,25)$. Although resistin is an adipokine for which there are significant data at the serum level, no study has yet investigated its mRNA levels in C57BL/6J mice as far as we are aware. Our findings showed a 2.13-fold and a 8.32-fold up-regulation of Retn level in mice on a HFD for 3 and 6 months, respectively, compared to the T0 control group, which is in agreement with the results of studies on human mRNA levels $(26,27)$. At the same time,

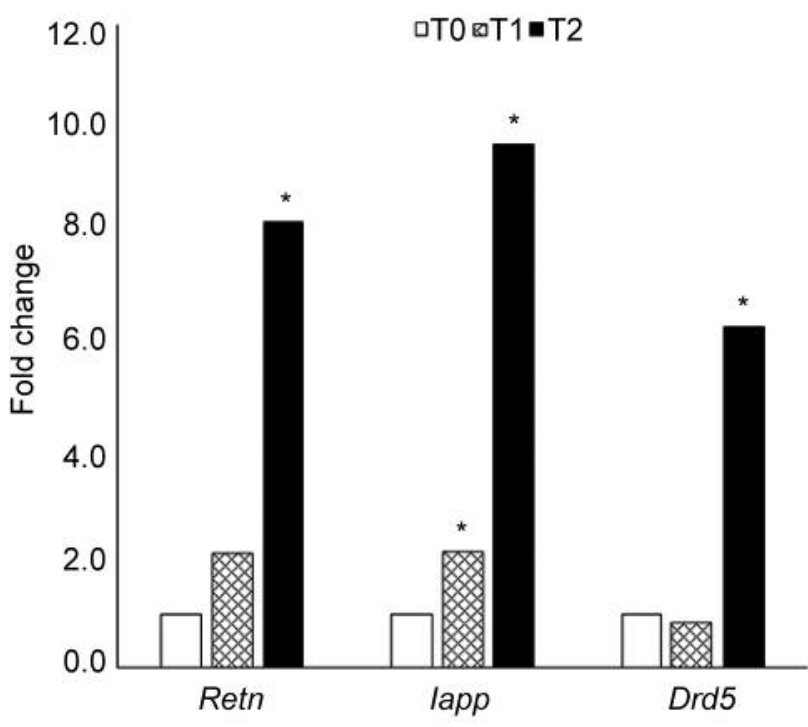

Figure 1. Expression of resistin (Retn), amylin (Iapp) and dopamine D1like receptor 5 (Drd5) genes in adipose tissue of control and obese mice: T0, Control group; T1, 60\% high-fat diet for 3 months; T2, 60\% high-fat diet for 6 months. *Significantly different from T0 at $p<0.01$.

serum levels of resistin were found to be higher in both HFD groups compared to the control group. Our data suggest that resistin may show a more significant increase in short-and long-term obesity models at the mRNA and serum levels.

In animal and human studies, it has been found that amylin reduces food intake. Smeltzer et al. applied social stress to amylin-treated rats and monitored their food intake habits, weight gain, and fat mass. The results of their study demonstrated that amylin suppresses food intake and reduces weight gain and fat mass (16). Roth et al. reported that amylin has anti-obesity effects in addition to its protective effects against the metabolic outcome of inflammation on the lean tissue in rats (15). Trevaskis et al. treated diet-induced obese rats with a combination of leptin and amylin and observed 10\% adipose tissue loss in rats (28). In another study in obese pediatric cases, amylin levels were examined before and after a weight loss program and a correlation between amylin level and insulin consumption and body mass index was observed (14). Iapp showed a 9.78-fold up-regulation in obese rats fed 6 months on a HFD compared to the control group in our study. This finding suggests that Iapp may be involved in an anabolic protection mechanism aiming to reduce an increased fat mass. As Iapp was increased in both T1 and T2 groups, this suggest that it exerts its role in both short-and long-term obesity at the mRNA level.

Recent studies have suggested that dopamine levels and receptors are also important in obesity (18-20). Positron 
emission tomography-computed tomography results showed that obese individuals have a lower density of dopamine receptors compared to healthy ones (19). On the other hand, there are a quite limited number of studies with regard to adipose tissue in the D1-like receptor family. In a study on rats that were subjected to low-and high-level exercise programs, Roberts et al. reported some findings that suggest a positive correlation between D1-like receptor and highperformance capacity. The results may be interpreted as indicating that certain problems in the D1-like receptor pathway may give rise to an inefficient phenotype in terms of physical activity in animal models (20). D1-Like receptors (DRD1 and DRD5) were demonstrated to be expressed at the mRNA and protein levels in adipose tissue (18). No other studies have been conducted on DRD5 in adipose tissue to our knowledge. In our study, the Drd5 mRNA level did not change significantly in the group fed HFD for 3 months compared to the control group (fold change $=0.81$ ); on the other hand, it was 6.36-fold higher in the group fed HFD for 6 months. This change may be linked to a major role of dopamine receptor-dependent adipogenesis in long-term obesity.

Obesity has frequently been modeled in rodents and other laboratory animals. C57BL/6J mice, among other lineages, is employed for HFD-induced obesity since they acquire a syndrome very similar to human metabolic syndrome. There are some studies exploring HFD-induced obesity with respect to serum and tissue mRNA levels of obesity markers in the short term $(29,30)$. In a recent study on $C 57 B L / 6 J$ mice with HFD-induced obesity, Ling et al. applied lipectomy and examined the mRNA levels of the genes of carbohydrate metabolism from hepatic and blood samples. Their results failed to show a significant difference between the short-and long-term groups (30). We found significant differences between the study groups with respect to the mRNA levels of Retn, Iapp, and Drd5 genes in adipose tissue. Our study revealed that genetic regulations differ in long-term and short-term obesity pathogenesis, and the obesity genetic model created by feeding mice of the C57BL/6J lineage a HFD was quite efficient for the examination of the genetic markers of the obesity model. Our next primary target includes the study of our cDNA and serum samples for other candidate genes and proteins involved in obesity pathogenesis.

\section{Conflicts of Interest}

The Authors state that there are no conflicts of interests in regard to this study.

\section{Acknowledgements}

The present work was supported by the Research Fund of Istanbul University, Project No: 9085.

\section{References}

1 Rayner G and Lang T: Obesity: Using the ecologic public health approach to overcome policy cacophony. In: Clinical Obesity in Adults and Children. Wiley-Blackwell, pp. 452-470, 2009.

2 Choquet H and Meyre D: Genetics of obesity: What have we learned? Curr Genomics 12: 169-179, 2011.

3 Inadera $\mathrm{H}$ : The usefulness of circulating adipokine levels for the assessment of obesity-related health problems. Int J Med Sci 5: 248-262, 2008.

4 Huang $X$ and Yang Z: Resistin's, obesity and insulin resistance: the continuing disconnect between rodents and humans. J Endocrinol Invest 39(6): 607-615, 2016.

5 Gabriely I, Ma XH, Yang XM, Atzmon G, Rajala MW, Berg $\mathrm{AH}$, Scherer P, Rossetti L and Barzilai N: Removal of visceral fat prevents insulin resistance and glucose intolerance of aging: an adipokine-mediated process? Diabetes 51(10): 2951-2958, 2002.

6 Levy JR, Davenport B, Clore JN and Stevens W: Lipid metabolism and resistin gene expression in insulin-resistant Fischer 344 rats. Am J Physiol Endocrinol Metab 282: 626-633, 2002.

7 Degawa-Yamauchi M and Bovenkerk JE, Juliar BE, Watson W, Kerr K, Jones R, Zhu Q and Considine RV: Serum resistin (FIZZ3) protein is increased in obese humans. J Clin Endocrinol Metab 88(11): 5452-5455, 2003.

8 Vendrell J, Broch M, Vilarrasa N, Molina A, Gómez JM, Gutiérrez C, Simón I, Soler J and Richart C: Resistin, adiponectin, ghrelin, leptin, and proinflammatory cytokines: relationships in obesity. Obes Res 12(6): 962-971, 2004.

9 Anderlová K, Kremen J, Dolezalová R, Housová J, Haluzíková D, Kunesová M and Haluzík M: The influence of very-lowcalorie-diet on serum leptin, soluble leptin receptor, adiponectin and resistin levels in obese women. Physiol Res 55(3): 277-283, 2006.

10 Lee JH, Chan JL, Yiannakouris N, Kontogianni M, Estrada E, Seip R, Orlova C and Mantzoros CS: Circulating resistin levels are not associated with obesity or insulin resistance in humans and are not regulated by fasting or leptin administration: crosssectional and interventional studies in normal, insulin-resistant, and diabetic subjects. J Clin Endocrinol Metab 88(10): 48484856, 2003.

11 Hay DL: Amylin. Headache 57: 89-96, 2017.

12 Ravussin E, Smith SR, Mitchell JA, Shringarpure R, Shan K, Maier H, Koda JE and Weyer C: Enhanced weight loss with pramlintide/metreleptin: an integrated neurohormonal approach to obesity pharmacotherapy. Obesity (Silver Spring) 17(9): 17361743, 2009.

13 Roth JD, Maier H, Chen S and Roland BL: Implications of amylin receptor agonism: integrated neurohormonal mechanisms and therapeutic applications. Arch Neurol 66: 306-310, 2009.

14 El-Rasheidy OF and Amin DA, Ahmed HA, El Masry H and Montaser ZM: Amylin level and gastric emptying in obese children: before and after weight loss. J Egypt Soc Parasit 42: 431-442, 2012.

15 Roth JD, Hughes H, Kendall E, Baron AD and Anderson CM: Antiobesity effects of the beta-cell hormone amylin in dietinduced obese rats: effects on food intake, body weight, composition, energy expenditure, and gene expression. Endocrinology 147: 5855-5864, 2006. 
16 Smeltzer M, Scott K, Melhorn S, Krause E and Sakai R: Amylin blunts hyperphagia and reduces weight and fat gain during recovery in socially stressed rats. Am J Physiol Regul Integr Comp Physiol 303: 676-682, 2012.

17 Vaughn AR, Davis MJ, Sivamani RK and Isseroff RR: A concise review of the conflicting roles of dopamine-1 versus dopamine2 receptors in wound healing. Molecules 23(1): E50, 2017.

18 Borcherding DC, Hugo ER, Idelman G, De Silva A, Richtand NW, Loftus $J$ and Ben-Jonathan N: Dopamine receptors in human adipocytes: expression and functions. PloS one 6: e25537, 2011

19 Volkow ND, Wang GJ, Fowler JS and Telang F: Overlapping neuronal circuits in addiction and obesity: evidence of systems pathology. Philos Trans R Soc Lond B Biol Sci 363: 3191-3200, 2008.

20 Roberts MD, Gilpin L, Parker KE, Childs TE, Will MJ and Booth FW: Dopamine D1 receptor modulation in nucleus accumbens lowers voluntary wheel running in rats bred to run high distances. Physiol Behav 105: 661-668, 2012.

21 Livak KJ, and Schmittgen TD: Analysis of relative gene expression data usingreal-time quantitative PCR and the 2 (-Delta Delta C (T)) method. Methods 25(4): 402-408, 2001.

22 Neymotin F and Nemzer LR: Locus of control and obesity. Front Endocrinol 5: 159, 2014.

23 Saunders CL, Chiodini BD, Sham P, Lewis CM, Abkevich V, Adeyemo AA, de Andrade M, Arya R, Berenson GS, Blangero J, Boehnke M, Borecki IB, Chagnon YC, Chen W, Comuzzie AG, Deng HW, Duggirala R, Feitosa MF, Froguel P, Hanson RL, Hebebrand J, Huezo-Dias P, Kissebah AH, Li W, Luke A, Martin LJ, Nash M, Ohman M, Palmer LJ, Peltonen L, Perola M, Price RA, Redline S, Srinivasan SR, Stern MP, Stone S, Stringham H, Turner S, Wijmenga $\mathrm{C}$ and Collier DA: Meta-analysis of genome-wide linkage studies in BMI and obesity. Obesity (Silver Spring) 15(9): 2263-2275, 2007.
24 Jamaluddin MS, Weakley SM, Yao Q and Chen C: Resistin: functional roles and therapeutic considerations for cardiovascular disease. Br J Pharmacol 165(3): 622-632, 2012.

25 García-Hermoso A and Ceballos-Ceballos RJ, Poblete-Aro CE, Hackney AC, Mota J and Ramírez-Vélez R: Exercise, adipokines and pediatric obesity: a meta-analysis of randomized controlled trials. Int J Obes (Lond) 41(4): 475-482, 2017.

26 McTernan CL, McTernan PG, Harte AL, Levick PL, Barnett AH and Kumar S: Resistin, central obesity, and type 2 diabetes. Lancet 359: 46-47, 2002.

27 McTernan PG, McTernan CL, Chetty R, Jenner K, Fisher FM, Lauer MN, Crocker J, Barnett AH and Kumar S: Increased resistin gene and protein expression in human abdominal adipose tissue. J Clin Endocrinol Metab 87(5): 2407, 2002.

28 Trevaskis JL, Lei C, Koda JE, Weyer C, Parkes DG and Roth JD: Interaction of leptin and amylin in the long-term maintenance of weight loss in diet-induced obese rats. Obesity 18: 21-26, 2010.

29 Ainslie DA, Proietto J, Fam BC and Thorburn AW: Short-term, high-fat diets lower circulating leptin concentrations in rats. Am J Clin Nutr 71: 438-442, 2000.

30 Ling BL, Chiu CT, Lu HC, Lin JJ, Kuo CY and Chou FP: Short and long-term impact of lipectomy on expression profile of hepatic anabolic genes in rats: a high fat and high cholesterol diet-induced obese model. PloS one 9: e108717, 2014.

Received February 22, 2018

Revised March 26, 2018

Accepted March 28, 2018 